Int. J. Odontostomat.,

8(2):309-315, 2014.

\title{
Frequency and Location of Referred Pain in Patients with Temporomandibular Disorder
}

\author{
Frecuencia y Ubicación del Dolor Referido en \\ Pacientes con Trastornos Temporomandibulares
}

\begin{abstract}
Monique Lalue Sanches ${ }^{*, *}$; Yara Juliano"**; Neil Ferreira Novo**; Carmen Paz Santibañez Hoyuela*; Vera Lucia Mestre Rosa*; Antonio Sérgio Guimarães*; Liete Figueiredo Zwir* \& Eduardo Cotecchia Ribeiro*
\end{abstract}

SANCHES, M. L.; JULIANO, Y.; NOVO, N. F.; HOYUELA, C. P. S.; ROSA, V. L. M.; GUIMARÃES, A. S.; ZWIR, L. F. \& RIBEIRO, E. C. Frequency and location of referred pain in patients with temporomandibular disorder. Int. J. Odontostomat., 8(2):309-315, 2014.

ABSTRACT: Based on the survey of records regarding the location and frequency of referred pain in patients with temporomandibular disorder when certain pre-established areas are palpated, we proposed an anatomical-topographical division of the head and neck to allow the standardization and reproducibility of locations of referred pain. Of the 835 charts reviewed, 419 (50.2\%) patients had referred pain on palpation of the regions based on the Research Diagnostic Criteria for Temporomandibular Disorders (RDC/TMD) and palpation of the cervical regions, as often analyzed by the Cochran $\mathrm{Q}$ test. The concordance coefficient of Kendall examined the correlation between regions of referred pain concerning to palpated sites. The new regions were defined preauricular, facial lateral, temporoparietal, posterior head, posterior and lateral cervical, anterior cervical and calvaria. The region palpated that originated more referred pain was corresponding to the masseter muscle followed by the region of the sternocleidomastoid muscle, regardless of the side palpated. On palpation of the regions established by the RDC/TMD, the most frequent area of referred pain was the lateral facial region. On palpation of the neck, were the posterior and lateral cervical regions. The sites that originated more referred pain when palpated were the masseter, temporalis, sternocleidomastoid and trapezius muscles.

KEY WORDS: anatomy, referred pain, facial pain, temporomandibular joint disorders, myofascial pain syndromes.

\section{INTRODUCTION}

Temporomandibular disorders (TMD) are a group of clinical conditions that affect the temporomandibular joint (TMJ), the muscles of mastication, and related structures. TMD may manifest as pain in the TMJ region and face, limited range of motion of the jaw, and joint sounds such as clicks and crepitus during jaw movement (de Leeuw, 2008; Sessle et al., 2008). A validated, standardized set of criteria for diagnosis of TMD is available: the Research Diagnostic Criteria for Temporomandibular Disorders (RDC/TMD) (Dworkin \& LeResche, 1992), which represent a work in progress and are continually reviewed and updated (Anderson et al., 2010; Schiffman et al., 2010).
The RDC/TMD Axis I clinical examination consists of palpation of the skin overlying specific muscles and of other regions to test for pathological changes. In cases of myofascial pain, palpation often elicits referred pain in regions remote from the site of palpation. This may be due to the presence of trigger points (TP or TrP), which are defined as hyper-irritable points usually located within a taut band of skeletal muscle or fascia of muscles. These points are tender to compression, which elicits a characteristic type of referred pain and autonomic phenomena (Simons et al., 1999; Simons, 2004).

\footnotetext{
* Morphology and Genetics Department, Escola Paulista de Medicina, Universidade Federal de São Paulo, São Paulo, Brazil.

** Dentistry Faculty, Universidade Santa Cecília, Santos, São Paulo, Brasil.

"** Public Health Department, Universidade Santo Amaro, São Paulo, Brazil.
} 
Charts and diagrams showing reference regions for pain on trigger-point palpation have been provided in several studies (Simons et al.; Wright, 2000; Svensson et al., 2003; Fernandez-de-las-Peñas et al., 2010a). However, these charts do not enable standardization and harmonization of pain regions with clinical parameters, thus hindering communication between health care professionals and, particularly, the systematic and consistent teaching of concepts and pain patterns.

In an attempt to address this gap, we propose a topographical and anatomical division of the head and neck, supported by an in-depth chart review of patients with TMD who reported referred pain on palpation. The location of pain was determined on the basis of this new model of head and neck regions, which in turn was based on predefined anatomical landmarks and imaginary lines so as to enable standardization, reproducibility, and universal use. During this survey, we also assessed the frequency of referred pain elicited by palpation of the skin overlying some specific muscles and other regions advocated in the literature.

\section{MATERIAL AND METHOD}

Charts and diagrams. On the basis of textbook representations of the topographic anatomy of the head and neck (Dauber, 2009), diagrams of referred pain associated with trigger-point palpation (Simons et al.), and sites of referred pain reported by a sample of patients interviewed in an outpatient setting, we delimited a series of new anatomical regions of the head and neck and created charts to illustrate these regions and their corresponding boundaries. Furthermore, some well-established regions were kept in this model.

Data collection. The data collection portion of this investigation consisted of a cross-sectional retrospective chart review. Overall, 835 charts of adult patients (age $>18$ years) seen at the Outpatient TMD and Orofacial Pain Clinic at Hospital São Paulo (Escola Paulista de Medicina da Universidade Federal de São Paulo, EPM-UNIFESP/HSP), São Paulo, Brazil, between January 2004 and December 2006 were randomly selected for analysis. All patients had been diagnosed with TMD by means of the RDC/TMD Diagnostic Criteria, which entail several targeted assessments, including palpation of the regions corresponding to the masseter and temporalis muscles, the submandibular region, and the posterior mandibular region for potential changes and pain. We also palpated the regions corresponding to the sternocleidomastoid and trapezius (descending or superior part) muscles and the suboccipital region to test for potential referred pain to these regions of the head and neck, which have been reported in a series of previous studies (Fernández-de-las-Peñas et al., 2007a, 2007b; Roth et al., 2007). All sites were palpated on the left and right. Of the 835 charts selected, only those corresponding to patients who had reported referred pain on palpation of the aforementioned regions were considered for further analysis. This reduced the sample to 419 patients, $368(87.83 \%)$ of whom were women and $51(12.17 \%)$ were men. Median age was 39 years (range, 18 to 90 years).

The study project was approved by the EPMUNIFESP/HSP Research Ethics Committee with protocol \#1987/09.

Statistical Analysis. The Mann-Whitney $U$ test was used to verify the potential association between sex and age distribution. Cochran's $Q$ test was used to assess the frequency of referred pain in each of the proposed regions of the head and neck elicited by palpation of predefined sites. Kendall's coefficient of concordance was used to test for agreement in the ranking of the most common regions of referred pain in relation to the sites of palpation (Siegel \& Castellan, 1988). The significance level was set at $0.05(5 \%)$ for all tests.

\section{RESULTS}

Of the 835 charts reviewed, 419 (50.2\%) were of patients in whom referred pain was elicited on head and neck palpation. The female-to-male ratio of the sample was approximately 7:1 (368 women, 51 men). As the Mann-Whitney $U$ test showed no statistically significant sex differences in age distribution $(Z=0.79$, $p=0.4305$ ), we pooled women and men into a single group for analysis. Cochran's $Q$ test showed a significant difference $(Q=419.44, p<0.0001)$ on analysis of the simultaneity of palpation sites that elicited referred pain in the predefined regions. The most common originating site of referred pain was the masseter muscle region, followed by the sternocleidomastoid muscle region, regardless of the side palpated (Table I). 
Table I. Instances of referred pain on the right and left sides as elicited by palpation of each site in 419 patients.

\begin{tabular}{lcc}
\hline Site of palpation $(\mathbf{n = 8 3 8 )}$ & Total instances & \% \\
\hline Masseter & 287 & 34.2 \\
Sternocleidomastoid & 178 & 21.2 \\
Temporalis & 157 & 18.7 \\
Posterior mandible & 113 & 13.5 \\
Trapezius & 78 & 9.3 \\
Submandibular & 77 & 9.2 \\
Suboccipital & 73 & 8.7
\end{tabular}

Cochran's $Q=419.44(p<0.0001)^{*}$. Note: The total number of instances of pain by site of palpation corresponds to the sum of instanced of referred pain reported by each patient on the right side, left side, or bilaterally.

The number of times that patients reported pain on palpation of each of the RDC/TMD-defined muscle sites or other regions, and on palpation of the trapezius, sternocleidomastoid, and suboccipital regions was ranked by region in decreasing order of frequency (Tables II and III). Kendall's coefficients were

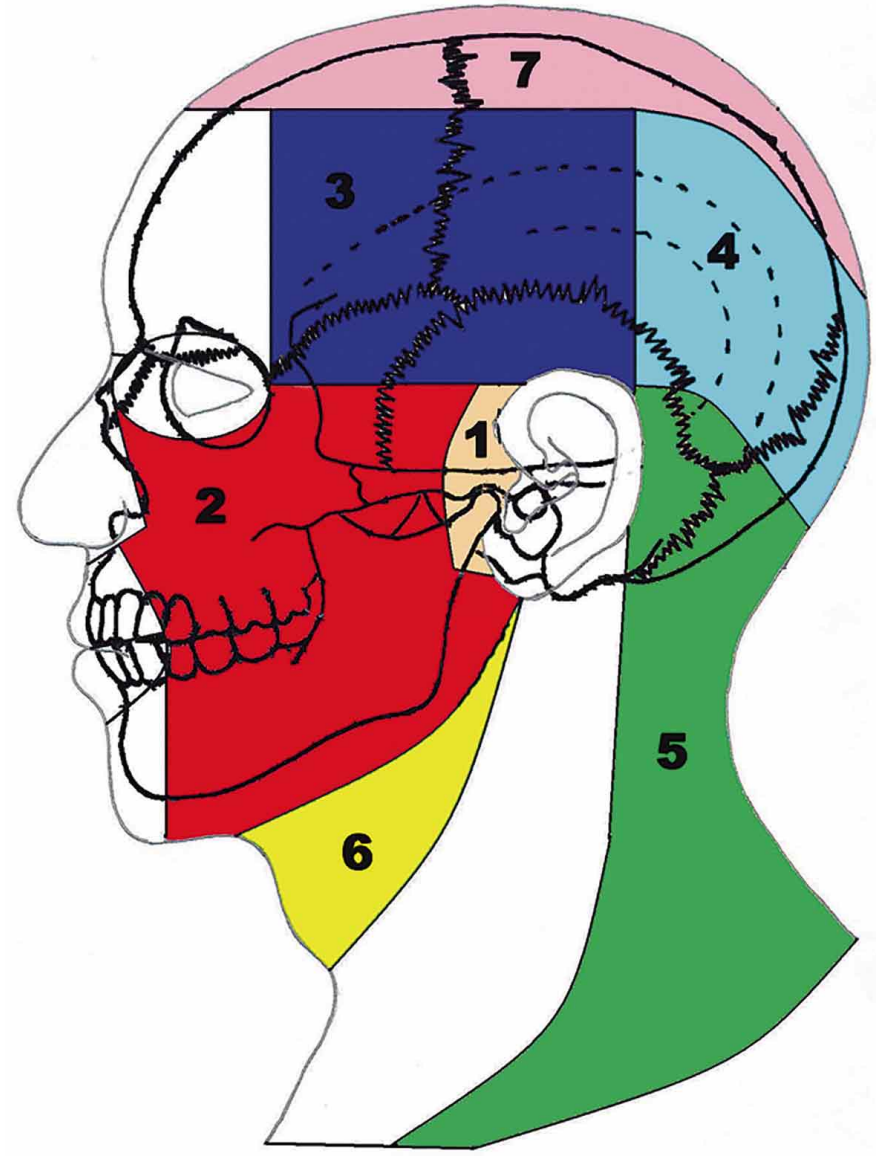

Fig. 1. Proposed Charts. The regions are: preauricular (1), lateral facial (2), temporoparietal (3), posterior head (4), posterior and lateral cervical (5), anterior cervical (6), and calvaria (7). calculated for the frequencies of referred pain on palpation in these two groups. There was agreement between regions of referred pain and sites of palpation: palpation of RDC/TMDdefined head sites, $W=0.7074(p=0.0004)$; palpation of defined neck sites, $W=0.7939$ $(p=0.0034)$. The most common site of referred pain on palpation of RDC/TMD-defined head sites was the lateral facial region, whereas the most common sites of referred pain on neck palpation were the posterior and lateral cervical regions.

Proposed charts. The orbital, nasal, oral (including the teeth, tongue, buccal mucosa, and gingival mucosa), mental, auricular, frontal, and sternocleidomastoid regions (all established anatomical regions of the head and neck) were kept in our model. The new regions are: preauricular, lateral facial, temporoparietal, posterior head, posterior and lateral cervical, anterior cervical, and calvaria (Fig. 1).

The boundaries of these proposed region are approximate, but they enable standardized, consistent description of specific sites of referred pain in TMD, whether by visualization or by palpation. It bears stressing that the lines used to define the boundaries of these regions are imaginary, but play an essential role in the proposed objective.

1. Preauricular region: Located immediately anterior to the auricular region, it is a narrow band that corresponds to the surface location of the temporomandibular joint. It is considered continuous with the lateral facial region .

2. Lateral facial region: A single region that constitutes an extension of the infra-orbital, zygomatic, buccal, and parotid masseteric regions, as previously defined in the Terminologia Anatomica.

3. Temporoparietal region: Bounded anteriorly by an ascending vertical line running from the lateral end of the superciliary arch to the superior boundary, which is a horizontal line that runs through the parietal tuber. The superior boundary ends posteriorly at an ascending vertical line that starts at the mastoid process, which constitutes the posterior boundary of this 
SANCHES, M. L.; JULIANO, Y.; NOVO, N. F.; HOYUELA, C. P. S.; ROSA, V. L. M.; GUIMARÃES, A. S.; ZWIR, L. F. \& RIBEIRO, E. C. Frequency and location of referred pain in patients with temporomandibular disorder. Int. J. Odontostomat., 8(2):309-315, 2014.

Table II. Distribution of referred pain stratified by the four RDC/TMD-defined sites of head palpation.

\begin{tabular}{|c|c|c|c|c|c|c|c|c|c|c|c|c|}
\hline \multirow[b]{3}{*}{ Region of referred pain } & \multicolumn{12}{|c|}{ Site of palpation } \\
\hline & \multicolumn{3}{|c|}{ Masseter } & \multicolumn{3}{|c|}{ Temporalis } & \multicolumn{3}{|c|}{ Posterior mandibular } & \multicolumn{3}{|c|}{ Submandibular } \\
\hline & Rank & $\mathbf{n}$ & $\%$ & Rank & $\mathbf{n}$ & $\%$ & Rank & $\mathbf{n}$ & $\%$ & Rank & $\mathbf{n}$ & $\%$ \\
\hline Preauricular & 3 & 78 & 14 & 5 & 20 & 7.1 & 2 & 31 & 19 & 2 & 16 & 15 \\
\hline Auricular & 4 & 57 & 10 & 7.5 & 14 & 5 & 3 & 27 & 17 & 6 & 7 & 6.7 \\
\hline Lateral facial & 1 & 125 & 23 & 1 & 90 & 32 & 1 & 32 & 20 & 1 & 38 & 36 \\
\hline Temporoparietal & 2 & 104 & 19 & 2 & 47 & 17 & 5 & 15 & 9.4 & 7 & 5 & 4.8 \\
\hline Frontal & 9.5 & 21 & 3.8 & 3 & 38 & 14 & 10 & 4 & 2.5 & 10 & 2 & 1.9 \\
\hline Calvaria & 14 & 1 & 0.2 & 12 & 1 & 0.4 & 13.5 & 0 & 0 & 13 & 0 & 0 \\
\hline Posterior head & 12 & 8 & 1.4 & 7.5 & 14 & 5 & 7 & 7 & 4.4 & 11 & 1 & 1 \\
\hline Posterior and lateral cervical & 9.5 & 21 & 3.8 & 6 & 18 & 6.4 & 8 & 5 & 3.1 & 8.5 & 4 & 3.8 \\
\hline Anterior cervical & 5 & 37 & 6.7 & 10 & 3 & 1.1 & 4 & 20 & 13 & 5 & 8 & 7.6 \\
\hline Sternocleidomastoid & 7.5 & 23 & 4.1 & 9 & 8 & 2.9 & 6 & 10 & 6.3 & 3.5 & 10 & 9.5 \\
\hline Nasal & 13 & 6 & 1.1 & 12 & 1 & 0.4 & 13.5 & 0 & 0 & 13 & 0 & 0 \\
\hline Orbital & 11 & 17 & 3.1 & 4 & 25 & 8.9 & 12 & 1 & 0.6 & 13 & 0 & 0 \\
\hline Oral & 6 & 35 & 6.3 & 14 & 0 & 0 & 10 & 4 & 2.5 & 3.5 & 10 & 9.5 \\
\hline Mental & 7.5 & 23 & 4.1 & 12 & 1 & 0.4 & 10 & 4 & 2.5 & 8.5 & 4 & 3.8 \\
\hline
\end{tabular}

Kendall's coefficient of concordance $(W)=0.7074(p=0.0004)^{*}$

Table III. Distribution of referred pain stratified by the three predefined sites of neck palpation.

\begin{tabular}{|c|c|c|c|c|c|c|c|c|c|}
\hline \multirow[b]{3}{*}{ Region of referred pain } & \multicolumn{9}{|c|}{ Site of palpation } \\
\hline & \multicolumn{3}{|c|}{ Sternocleidomastoid } & \multicolumn{3}{|c|}{ Suboccipital } & \multicolumn{3}{|c|}{ Trapezius } \\
\hline & Rank & $\mathbf{n}$ & $\%$ & Rank & $n$ & $\%$ & Rank & $\mathbf{n}$ & $\%$ \\
\hline Preauricular & 6 & 20 & 6.8 & 12.5 & 0 & 0 & 12 & 0 & 0 \\
\hline Auricular & 7 & 18 & 6.1 & 6 & 5 & 4.2 & 8 & 2 & 1.9 \\
\hline Lateral facial & 2 & 58 & 20 & 5 & 12 & 10 & 3 & 11 & 11 \\
\hline Temporoparietal & 3 & 38 & 13 & 2 & 26 & 22 & 4 & 10 & 9.7 \\
\hline Frontal & 8 & 15 & 5.1 & 4 & 13 & 11 & 5.5 & 5 & 4.9 \\
\hline Calvaria & 14 & 0 & 0 & 8.5 & 2 & 1.7 & 12 & 0 & 0 \\
\hline Posterior head & 9.5 & 8 & 2.7 & 3 & 16 & 13 & 5.5 & 5 & 4.9 \\
\hline Posterior and lateral cervical & 1 & 79 & 27 & 1 & 40 & 33 & 1 & 52 & 51 \\
\hline Anterior cervical & 4 & 23 & 7.8 & 12.5 & 0 & 0 & 7 & 4 & 3.9 \\
\hline Sternocleidomastoid & 5 & 22 & 7.5 & 7 & 3 & 2.5 & 2 & 13 & 13 \\
\hline Nasal & 11 & 2 & 0.7 & 8.5 & 2 & 1.7 & 12 & 0 & 0 \\
\hline Orbital & 9.5 & 8 & 2.7 & 10 & 1 & 0.8 & 9 & 1 & 1 \\
\hline Oral & 12.5 & 1 & 0.3 & 12.5 & 0 & 0 & 12 & 0 & 0 \\
\hline Mental & 12.5 & 1 & 0.3 & 12.5 & 0 & 0 & 12 & 0 & 0 \\
\hline
\end{tabular}

Kendall's coefficient of concordance $(W)=0.7939(p=0.0034)^{*}$

region. Its inferior boundary is a horizontal line running from the lateral palpebral commissure, flush with the uppermost point of the helix, to the posterior boundary as described above.

4. Posterior region of the head: Constitutes the posterior extension of the line proposed as the superior boundary of the temporoparietal region, running all the way to the lambda. This imaginary line corresponds to the superior boundary of the posterior region of the head. Its anterolateral boundary is coterminous with the posterior boundary of the temporoparietal region, and its posteromedial boundary is the posterior midline of the head. Its inferior boundary is an extension of the inferior boundary of the temporoparietal region running to the external occipital protuberance.

5. Posterior and lateral cervical region: This region is bounded posteromedially by the posterior midline of the neck and superiorly by the inferior boundary of the posterior region of the head. Its anterolateral boundary is an extension of the anterolateral boundary of the posterior region of the head, as a descending line that runs down from the mastoid process along the poste- 
rior margin of the sternocleidomastoid muscle. It is bounded inferiorly by the middle and posterior thirds of the shaft of the clavicle.

6. Anterior cervical region: Bounded posterolaterally by the sternocleidomastoid muscle region; this region encompasses the submandibular, submental, carotid, and muscular triangles. Although the submental triangle is a single structure, the anteromedial boundary of this region, defined by the anterior midline of the head and neck, divides it into two halves (right and left). Its superior boundary is coterminous with the inferior boundary of the lateral facial region, that is, the inferior border of the mandible.

7. Calvaria region: From an anatomical standpoint, the calvaria is the skullcap, the dome- or cap-shaped upper part of the cranium. In our proposed model, however, this region is bounded by lines that run through the right and left parietal tubers and meet posteriorly at the lambda and anteriorly at the forehead, thus constituting the superior boundary of the frontal region.

All of these regions, except for the calvaria, are paired (right side and left side).

\section{DISCUSSION}

Several studies have demonstrated the relationship between temporomandibular disorder (TMD) and the presence of referred pain in the orofacial region (Simons et al.; Wright; Svensson et al.; SchmidtHansen et al., 2006; Svensson, 2007; Fernandez-delas-Peñas et al., 2010a, 2010b), which may originate in the muscles of mastication or in other regions associated with this process, such as some cervical muscle groups (Fernández-de-las-Peñas et al., 2007a; Fernández-de-las-Peñas et al., 2007b; Roth et al.).

The proportion of women with TMD observed in our sample was slightly higher than that reported in the literature, in which the female-to-male ratio ranges from 3:1 to 6:1 (de Leeuw). The 7:1 ratio observed in our sample may be explained by the fact that women are more likely to seek medical attention for health treatment (Warren \& Fried, 2001).

Referred pain exhibits specific patterns. Of the predetermined regions established for analysis in this study, that most commonly associated with referred pain was the lateral facial region, corroborating the findings of Wright. The palpation site that most commonly elicited referred pain was the masseter muscle region, followed by the sternocleidomastoid and the temporalis muscles regions, disagreeing with Wright (2000), in which palpation of the trapezius muscle region was most likely to elicit referred pain, followed by palpation of the lateral pterygoid and of the masseter. Schmidt-Hansen et al. (2006) showed that referred pain elicited by palpation of the masseter and temporalis (anterior portion) muscles is exclusively associated with the trigeminal territory. Conversely, referred pain elicited by palpation of the trapezius muscle region is rarely associated with the trigeminal nerve distribution. These data stand in contradistinction to our finding that the third (lateral facial) and fourth (temporoparietal) proposed regions were the most common sites of referred pain on palpation of the trapezius muscle region, as both regions are innervated exclusively by the trigeminal nerve.

In our sample, the most common sites of referred pain on palpation of the sternocleidomastoid muscle region were the posterior and lateral cervical regions, followed by the lateral facial region and the temporoparietal region. However, studies have shown that referred pain elicited by palpation of the sternocleidomastoid muscle region often presents in regions innervated by the ophthalmic and maxillary nerves of the trigeminal nerve (Schmidt-Hansen et al.; Fernández-de-las-Peñas et al., 2010a).

Although some studies have reported a high frequency of referred tooth pain elicited by palpation of trigger points on the masseter and temporalis muscles (Wright; Fernández-de-las Peñas et al., 2010a), we did not obtain a similar result.

The difference between our findings and those reported previously in the literature may be attributable to the diversity of mechanisms that have been investigated in an attempt to explain referred pain. One theory that attempts to explain this phenomenon is the convergence-projection theory, which maintains there are more nerves conducing nociceptive information to the central nervous system (CNS) than neurons conducing this information to the supra-segmental components of the CNS. Therefore, these higher centers receive information in such a way that pain originating from a single area may be perceived as originating in two or more distinct regions. The orofacial region features an extensive convergence of sensory nerves, which, in addition to the originating nociceptive impulses through the trigeminal nerve, also originates 
impulses through the facial, glossopharyngeal, vagus, hypoglossal, and superior cervical nerves (Wright; Sessle et al.). Another factor that appears to contribute to the development of referred pain is the process of central sensitization, whereby continuous nociceptive stimuli may activate specific receptors that increase the sensitization of neurons. This leads to a change in processing of nerve impulses in higher centers, expanding the receptive field so that non-nociceptive impulses are interpreted as pain (Svensson et al.; Fernandez-de-las-Peñas et al., 2010a).

In view of the method used in this study (palpation of muscle sites), we stress that our hypothesis is based on the presence of myofascial trigger points (TP, MTrP) that can be activated by palpation to elicit referred pain. TPs are hyper-irritable points located within a taut band of striated muscle or fascia of muscle. Their pathophysiology involves an "energy crisis" due to excessive acetylcholine release, which compromises tissue integrity and releases algogenic and neuroactive substances that induce the characteristic tenderness to palpation, local contractile response and referred pain recognized as the "pain complaint" (Simons).

In addition to the wide range of known possible mechanisms for referred pain, other limitations may account for the divergences between our findings and those reported elsewhere in the literature:

1- Absence of a control group, which would enable confrontation of palpation findings;
2- As data collection was carried out between 2004 and 2006, palpation was performed by different examiners, all of whom had received the same training, precluding assessment of inter-rater correlation;

3- Some previous studies had very small sample sizes, and most focused on female subjects.

\section{CONCLUSION}

Our development of head and neck region charts enabled definition of a broad, standardized classification of referred pain elicited by palpation of specific sites. This region model can be used to standardize and facilitate communication among professionals involved in the study of this topic.

The RDC/TMD-defined sites of palpation that most commonly elicited referred pain were the masseter and temporalis muscles regions. The neck sites that most commonly elicited referred pain were the sternocleidomastoid and trapezius muscles regions.

The most common sites of referred pain on palpation of RDC/TMD sites in our new proposed model of head and neck regions were the lateral facial, temporoparietal, posterior and lateral cervical, and preauricular regions. The most common sites of referred pain on neck palpation were the posterior and lateral cervical regions.

SANCHES, M. L.; JULIANO, Y.; NOVO, N. F.; HOYUELA, C. P. S.; ROSA, V. L. M.; GUIMARÃES, A. S.; ZWIR, L. F. \& RIBEIRO, E. C. Frecuencia y ubicación del dolor referido en pacientes con trastornos temporomandibulares. Int. J. Odontostomat., 8(2):309-315, 2014.

RESUMEN: Basado en la encuesta de registros relativos a la ubicación y frecuencia de dolor referido en pacientes con trastorno temporomandibular al palpar ciertas áreas preestablecidas, propusimos una division topográfica anatómica de cabeza y cuello para permitir la estandarización y reproducibilidad de los lugares de dolor referido. Al examinar los gráficos de 835 sujetos, 419 un $(50,2 \%)$ de los pacientes reportaron dolor referido a la palpación de las regiones sobre la base de los Criterios Diagnósticos para la Investigación de Trastornos Temporomandibulares (CDI/TTM) y palpación de la region cervical, con análisis de frecuencia con prueba de Cochran Q. El coeficiente de concordancia de Kendall examinó la correlación entre las regiones de dolor referido en relación a los sitios palpados. Las regiones nuevas fueron definidas como, pre-auricular, facial lateral, temporoparietal, cabeza posterior, posterior y lateral cervical, cervical anterior y bóveda craneal. La región de palpado en la cual se originó el dolor mencionado con mayor frecuencia, corresponde al músculo masetero, seguido por la región del músculo esternocleidomastoideo, independientemente del lado palpado. Durante la palpación de las regiones establecidas por los CDI/TTM, la zona más frecuente de dolor referido fue la región facial lateral. A la palpación del cuello, el dolor referido se reportó en la parte posterior y en las regiones cervicales laterales. Los sitios en los que se originó el mayor dolor referido a la palpación, fueron los músculos maseteros, músculos temporales, esternocleidomastoideo y trapecio.

PALABRAS CLAVE: anatomía, dolor referido, dolor facial, trastornos de articulación temporomandibular, trastornos de dolor miofascial. 


\section{REFERENCES}

Anderson, G. C.; Gonzalez, Y. M.; Ohrbach, R.; Truelove, E. L.; Sommers, E.; Look, J. O. \& Schiffman, E. L. The Research Diagnostic Criteria for Temporomandibular Disorders. VI: future directions. J. Orofac. Pain, 24(1):7988, 2010.

Dauber, W. Dicionário ilustrado de anatomia de Feneis. 9a ed. São Paulo, Artmed, 2009.

de Leeuw, R. Orofacial Pain: Guidelines for Assessment, Diagnosis, and Management. $4^{\text {th }}$ ed. Chicago, Quintessence, 2008.

Dworkin, S. F. \& LeResche, L. Research diagnostic criteria for temporomandibular disorders: review, criteria, examinations and specifications, critique. J. Craniomandib. Disord., 6(4):301-55, 1992.

Fernández-de-Las-Peñas, C.; Cuadrado, M. L.; ArendtNielsen, L.; Simons, D. G. \& Pareja, J. A. Myofascial trigger points and sensitization: an updated pain model for tension-type headache. Cephalalgia, 27(5):383-93, 2007a.

Fernández-de-Las-Peñas, C.; Ge, H. Y.; Arendt-Nielsen, L.; Cuadrado, M. L. \& Pareja, J. A. Referred pain from trapezius muscle trigger points shares similar characteristics with chronic tension type headache. Eur. J. Pain, 11(4):475-82, 2007b.

Fernández-de-Las-Peñas, C.; Galán-del-Río, F.; AlonsoBlanco, C.; Jiménez-García, R.; Arendt-Nielsen, L. \& Svensson, P. Referred pain from muscle trigger points in the masticatory and neck-shoulder musculature in women with temporomandibular disoders. J. Pain, 11(12):1295304, 2010a.

Fernández-de-Las-Peñas, C.; Ge, H. Y.; Alonso-Blanco, C.; González-Iglesias, J. \& Arendt-Nielsen, L. Referred pain areas of active myofascial trigger points in head, neck, and shoulder muscles, in chronic tension type headache. J. Bodyw. Mov. Ther., 14(4):391-6, 2010b.

Roth, J. K.; Roth, R. S.; Weintraub, J. R. \& Simons, D. G. Cervicogenic headache caused by myofascial trigger points in the sternocleidomastoid: a case report. Cephalalgia, 27(4):375-80, 2007.

Schiffman, E. L.; Ohrbach, R.; Truelove, E. L.; Tai, F.; Anderson, G. C.; Pan, W.; Gonzalez, Y. M.; John, M. T.; Sommers, E.; List, T.; Velly, A. M.; Kang, W. \& Look, J. O. The Research Diagnostic Criteria for Temporomandibular Disorders. V: methods used to establish and validate revised Axis I diagnostic algorithms. J. Orofac. Pain, 24(1):63-79, 2010.
Schmidt-Hansen, P. T.; Svensson, P.; Jensen, T. S.; GravenNielsen, T. \& Bach, F. W. Patterns of experimentally induced pain in pericranial muscles. Cephalalgia, 26(5):568-77, 2006.

Sessle, B. J.; Lavigne, G. J.; Lund, J. P. \& Dubner, R. Orofacial Pain: From Basic Science to Clinical Management. $2^{\text {nd }}$ ed. Chicago, Quintessence, 2008.

Siegel, S. \& Castellan, N. J. Jr. Nonparametric Statistics for the Behavioral Sciences. $2^{\text {nd }}$ ed. New York, McGraw-Hill, 1998. pp.170-4.

Simons, D. G.; Travell, J. G. \& Simons, L. S. Travell and Simons Myofascial Pain and Dysfunction. The Trigger point manual, upper half of body. Vol. 1. 2nd ed. Baltimore, Williams \& Wilkins, 1999.

Simons, D. G. Review of enigmatic MTrPs as a common cause of enigmatic musculoskeletal pain and dysfunction. J. Electromyogr. Kinesiol., 14(1):95-107, 2004.

Svensson, P.; Bak, J. \& Troest, T. Spread and referral of experimental pain in different jaw muscles. J. Orofac. Pain, 17(3):214-23, 2003.

Svensson, P. Muscle pain in the head: overlap between temporomandibular disorders and tension-type headaches. Curr. Opin. Neurol.,20(3):320-5, 2007.

Warren, M. P. \& Fried, J. L. Temporomandibular disorders and hormones in women. Cells Tissues Organs, 169(3):187-92, 2001.

Wright, E. F. Referred craniofacial pain patterns in patients with temporomandibular disorder. J. Am. Dent. Assoc., 131(9):1307-15, 2000.

Correspondence to:

Monique Lalue Sanches

Rua Pereira da Nóbrega, \#324, ap. 43

CEP:01549-020 - São Paulo

BRAZIL

Email: monique.lalue@unifesp.br

Received: 12-09-2013

Accepted: 16-02-2014 